\title{
THE CHEMISTRY OF SNOW AND MELTWATERS WITHIN THE MESOSTRUCTURE OF A BOREAL FOREST SNOW COVER
}

by

\author{
H.G. Jones
}

(INRS-Eau, Université du Québec, C.P. 7500, Sainte-Foy, P.Q. G1V 4C7, Canada)

\section{ABSTRACT}

A physical and chemical study of snow mesostructure was carried out in a boreal forest site at Lake Laflamme, Quebec in spring 1983. The concomitant physical observations and $\delta^{18} \mathrm{O} \%$ data on the upper layers led to the reconstruction of recent snowfall events and meltwater movements which influenced the chemistry of snow at different levels of the snowpack. Correlations between data relating the concentrations of atmospheric pollutants in snow strata were significant $\left(\mathrm{H}^{+}, \mathrm{SO}_{4}^{2-}, \mathrm{r}=0.89 ; \mathrm{H}^{+}\right.$, $\left.\mathrm{NO}_{3}^{-}, \mathrm{r}=0.81, \mathrm{P} \leqslant 0.001\right)$. The grouping of chemical species by factor analysis distinguished clearly between ionic species originating from the long-range transport of atmospheric pollutants and those due to local deposition phenomena and organic debris from the forest canopy. Mesostructural characteristics led to heterogeneous flow patterns of meltwater and rainwater through the snow cover. Both physical and chemical characteristics of the snow mesostructure change rapidly in a non-uniform manner under such conditions. This leads to increased difficulties in the interpretation of data gathered during snow sampling studies on pack decay during the spring run - off period.

\section{INTRODUCTION}

The chemical evolution of snow cover depends both on deposition phenomena (wet and dry deposition of acidic pollutants, local dust and organic debris) and on subsequent ionic and organic transformations in the pack (Jones and Sochanska 1985). Although samples taken by means of snow cores (Jeffries and Snyder 1981) and/or integrated samples from snow-pits (Adams and others 1982) are used to follow general chemical trends in snowpack evolution, the complex nature of the structural characteristics of the pack such as snow strata, ice lenses, localized debris and voids make it difficult to follow in-pack chemical transformations from the data obtained.

This is particularly true for snow cover in boreal forest sites where a large amount of organic debris is continually deposited from the canopy. Its presence is such a dominant feature of snow cover evolution that problems are encountered both in sampling procedures and in the interpretation of the data relating the quality of incident precipitation with that of the snowpack (Jones and Sochanska 1985). In particular, the spatial irregularity in the deposition of large amounts of debris causes variations in the physical nature of the snow cover. This, in turn, can influence meltwater flow and cause spatial variability in the chemical content of the snowpack, particularly during periods when the presence of free water (meltwater and/or rain) is appreciable.

Most of the organic debris falls from the canopy between precipitation episodes and can be removed during the sampling of discrete strata in the snow cover. In contrast, snow cores are of ten contaminated with large amounts of organic debris collected during the sampling procedure. It was thus thought that data from snow strata could offer more precise information on the possible mechanisms for the transformation of chemical components from atmospheric aerosols in the snowpack. In the spring of 1983, an intensive study on the evolution of chemical species $\left(\mathrm{H}^{+}, \mathrm{NH}_{4}^{+}, \mathrm{Na}^{+}, \mathrm{K}^{+}, \mathrm{Ca}^{2+}, \mathrm{Mg}^{2+}, \mathrm{Al}, \mathrm{Mn}\right.$,
$\mathrm{Cl}^{-}, \mathrm{NO}_{3}^{-}, \mathrm{SO}_{4}^{2-}, \mathrm{PO}_{4}^{3-}$ ) in snow cores (168 samples) and snow strata (95 samples) was carried out during spring at the Lake Laflamme watershed (Jones and others 1984). This present article discusses the distribution and evolution of ionic species in the snowpack and its component strata observed before and during the spring melt period of 1983. To define the successive arrangements of strata in the vertical profile of a snowpack, I have adopted the term "mesostructure". The term was used in this sense by Langham (1974); it should be noted, however, that the definition of Langham differs from that of McKay and Gray (1981) for the mesostructure of snow cover in general.

\section{METHODOLOGY
Study area and sampling sites}

The watershed Lake Laflamme $\left(0.68 \mathrm{~km}^{2}\right)$ lies between 777 (mean lakewater level) and $884 \mathrm{~m}$ altitude at lat $47^{\circ} 19^{\prime} \mathrm{N}$ and long $71^{\circ} 0^{\prime} \mathrm{W}$ in the Montmorency Forest, $80 \mathrm{~km}$ to the north of the city of Quebec, Canada. The study area, sampling sites and sampling frequency for snow cores are described in Jones and others (1984). Three snow-profile stations (A and B under intermediate forest canopy cover, C in open area) were sampled once only for the chemical stratigraphy study on 9 April 1983 when all strata were collected. Site $\mathrm{A}$ was $4 \mathrm{~m}$ to the south-west of site B while site C was $11 \mathrm{~m}$ to the east of site B.

Different strata were identified by eye (organic debris and/or morphic state of snow grains) or by touch (ice lenses). Although the method is subjective, it works well; cross-checks with three observers in the field showed that the mesostructure of the snow cover as recorded by each observer agreed to within $90 \%$ of all the snow strata identified (87 samples). This percentage success rate drops $(\approx 75 \%)$ and becomes more erratic after spring melt starts.

Samples for the chemical analysis of the snow cover were obtained by coring with a clear plastic tube (plexiglas $2 \mathrm{~m}$ long and $7.5 \mathrm{~cm}$ in diameter) (Jeffries and Snyder 1981). Individual snow strata were also cored with the same device by inserting it horizontally into the face of the snow-pit. The snow-pits (Adams and others 1982) were dug to permit a better appreciation of the physical mesostructure of the snow cover and the removal of separate snow strata with large plastic spatulas $(26 \times 26$ $\mathrm{cm})$.

As the deposition of organic debris from the canopy is heterogeneous, large particulate material was removed manually from the top of each stratum during the sampling. All samples were placed in plastic bags (polyethylene) and kept at $-20^{\circ} \mathrm{C}$ until melted for analysis.

To determine the meltwater flow patterns at different levels of the snowpack structure, small lysimeters constructed from ABS tubing cut lengthwise $(10 \mathrm{~cm} \mathrm{x} 1 \mathrm{~m}$ and $12.5 \mathrm{~cm} \times 1 \mathrm{~m}$ ) were inserted at the interfaces between the different strata at sites $A$ and $B$ on 12 April 1983. The lysimeters were placed in a vertical staggered pattern in the faces of the snow-pits in order to avoid interference of one lysimeter with another during the movement of meltwater through the pack. 


\section{Analytical procedures}

Analytical procedures ( $\mathrm{pH}$, conductivity, major ions, $\left[\mathrm{Cl}^{-}, \mathrm{NO}_{3}^{-}, \mathrm{SO}_{4}^{2-}, \mathrm{PO}_{4}^{3-}, \mathrm{Na}^{+}, \mathrm{K}^{+}, \mathrm{Ca}^{2+}, \mathrm{Mg}^{2+}, \mathrm{NH}_{4}^{+}\right] \mathrm{Al}$ and $\mathrm{Mn}$ ) and detection limits are described in Jones and Sochanska (1985).

Isotopic $\left(6^{18} \mathrm{O}\right)$ determinations were carried out at the geochemical laboratories at the Department of Earth Sciences, Université du Québec à Montréal, Montréal, Data analysis

Although a total of 32 distinct strata were originally sampled at sites A, B and C, some of the larger ice lenses were removed separately from snow strata at some sites but not at others. In order to compare the chemical contents of all equivalent strata at the three sites, some ionic concentrations had to be recalculated on volume-weighted basis for some combinations of ice lenses and strata which originally had been sampled as separate entities.

\section{RESULTS AND DISCUSSION}

Snow strata: physical and chemical stratigraphy

The structure of the snowpack which reflected the main accretion phase (22 March-8 April) of 1982 to 1983

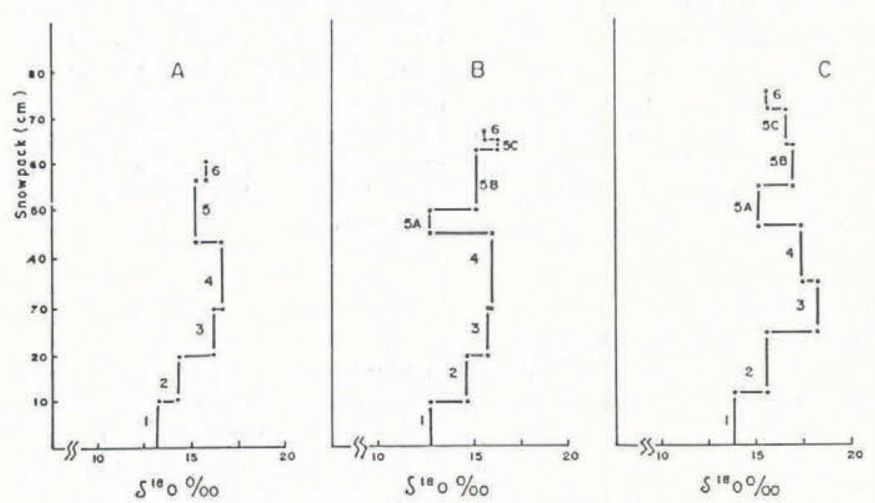

Fig.1. Mesostructure and $\delta^{18} \mathrm{O}$ concentrations $(\% \circ)$ in individual snow strata, Lake Laflamme, 1983. (snow $76.8 \mathrm{~cm}$ ) with no water loss attained a maximum mean value for the water equivalent $(21.2 \pm 3.94 \mathrm{~cm})$ on 8 April 1983.

Figures 1, 2, 3 and 4 show the mesostructure (strata 1 to 6$)$ and the vertical profiles for $\delta^{18} \mathrm{O}(\% \circ), \mathrm{SO}_{4}^{2-}, \mathrm{H}^{+}$ and $\mathrm{Cl}^{-}$for the snow cover at sites $\mathrm{A}, \mathrm{B}$ and $\mathrm{C}$ on 9 April at the start of the spring melt. From meteorological records and earlier data on the snow cover at Lake Laflamme obtained before the sampling period it was possible to identify the prominent strata 5 and 6 with past precipitation events. Stratum 5 was the result of two heavy snowfalls on 22 March $(28.7 \mathrm{~cm})$ and 27 March $\left(26.9 \mathrm{~cm}\right.$ ), separated by a cold period (mean $\left.-14^{\circ} \mathrm{C}\right)$, and stratum 6 reflected the snowfalls of 3 to 5 April $(12.5$ $\mathrm{cm}$ ) and the mixed precipitation of 8 April (snow $3.8 \mathrm{~cm}$, rain $0.6 \mathrm{~cm}$ ). The snow profiles of $A, B$ and $C$ were very similar except that stratum 5 in $A$ was found to be separated in $B$ and $C$ into three strata $(5 a, 5 b$, and $5 c)$ by thin ice crusts. These ice crusts, which were very fragile, were judged to be the result of diurnal melts and ref reezing of the meltwater which took place on 5 and 6 April respectively. The lower strata ( 1 to 4 ) were easy to identify from structural characteristics such as large ice lenses but it was difficult to relate them to any combination of events or meteorological conditions.

In spite of the differences in pack depth (A: $60 \mathrm{~cm}$, B: $67 \mathrm{~cm}, C$ : $76 \mathrm{~cm})$, the very regular and common pattern in the vertical profile shown by the three stations show that wind redistribution at ground level is not an important factor in determining the morphological characteristics in the type of forest cover found at Lake Laflamme. This would also seem to be in accord with the close similarities observed between the $\delta^{18} \mathrm{O} \%$ profiles for $\mathrm{A}, \mathrm{B}$ and $\mathrm{C}$ (Fig.1). This similarity in the $\delta^{18} \mathrm{O} \%$ of equivalent strata at each site would indicate that each stratum has been generally subjected to the same combination of physical phenomena (deposition, metamorphism, evaporation and melt) other than wind distribution.

From a consideration of the relative values of $6^{18} \mathrm{O} \%$ o between strata $5 \mathrm{a}$ and $5 \mathrm{~b}$ at both sites $\mathrm{B}$ and $\mathrm{C}$, it can be seen that the heavier isotope $\left({ }^{18} \mathrm{O}\right)$ is

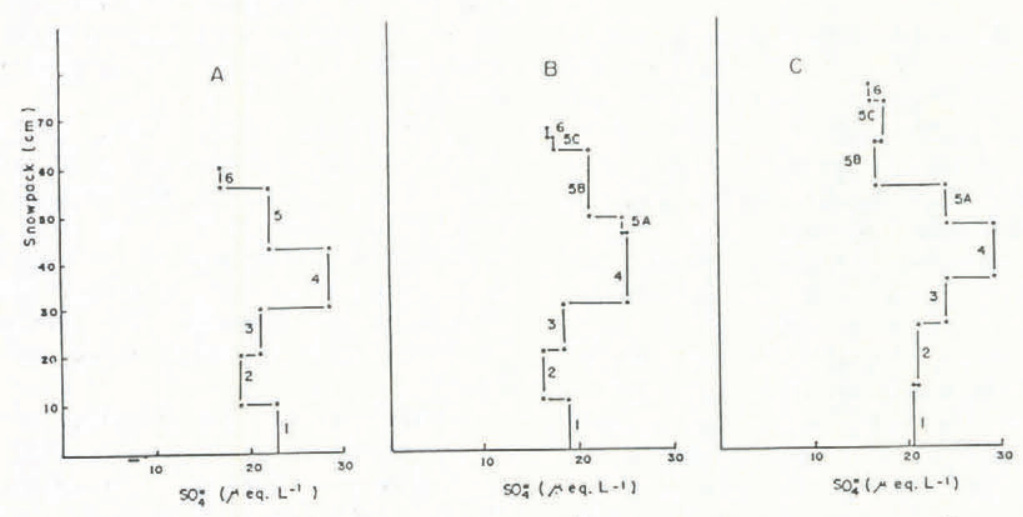

Fig.2. Mesostructure and $\mathrm{SO}_{4}^{2-}$ concentrations ( $\mu$ eq $1^{-1}$ ) in individual snow strata, Lake Laflamme, 1983.
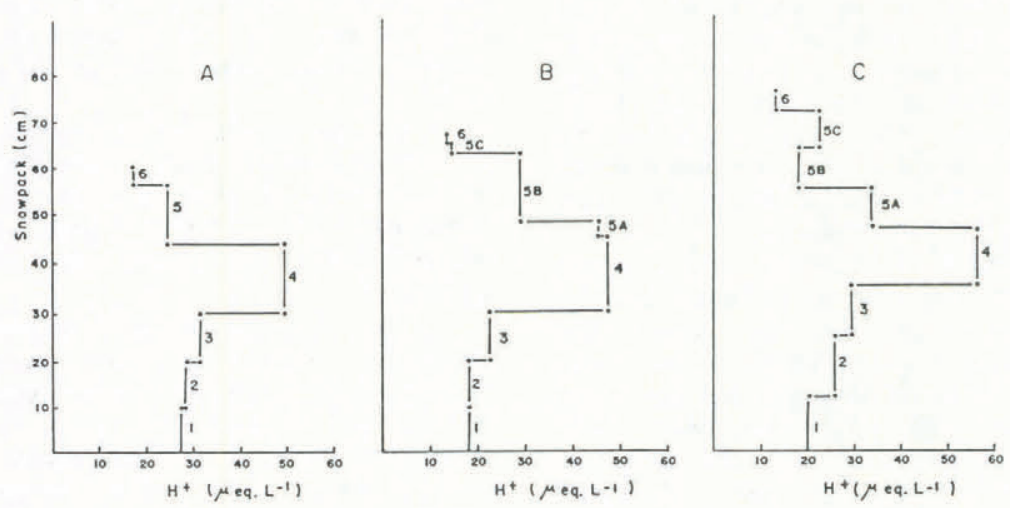

Fig.3. Mesostructure and $\mathrm{H}^{+}$concentrations ( $\mu$ eq $\mathrm{l}^{-1}$ ) in individual snow strata, Lake Laflamme, 1983. 

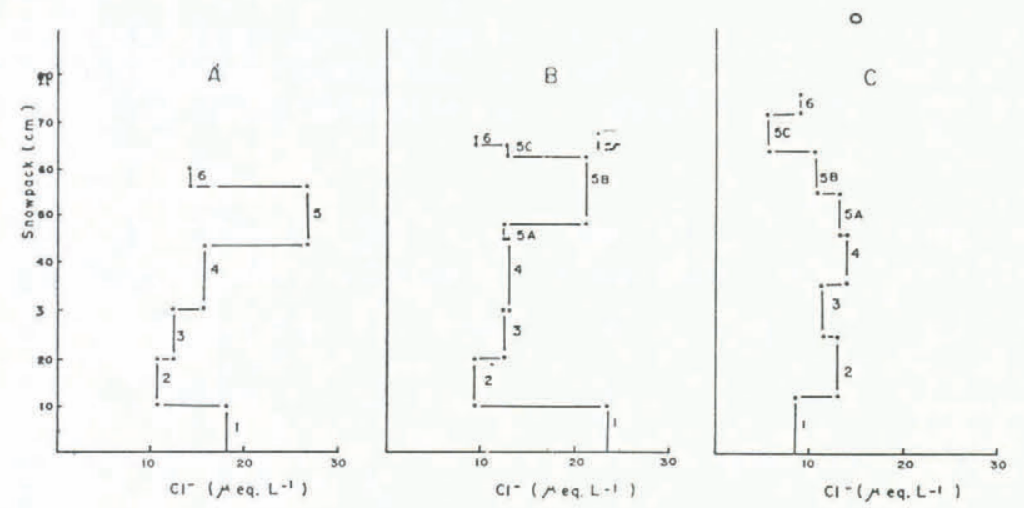

Fig.4. Mesostructure and $\mathrm{Cl}^{-}$concentrations ( $\mu$ eq $\mathrm{1}^{-1}$ ) in individual snow strata, Lake Laflamme, 1983.

concentrated in the lower regions of stratum 5. As the material in the original stratum was composed of snow from only two major snowfall events, this relative distribution of the lighter and heavy isotopes would indicate that the meltwater moving down from stratum 5 into the lower strata of the pack is preferentially enriched in the lighter isotope. Herrmann and others (1981) have reported that meltwater issuing from snowpacks in both natural and simulated melts shows a ${ }^{16} \mathrm{O}$ enrichment compared to the residual snow. These results agree with the presence of the two ice crusts which were previously identified with diurnal melt and freeze cycles occurring three or four days before the sampling period. The $\delta^{18} \mathrm{O}^{\circ} \%$ differences between sites are significant as the $\delta^{18} \mathrm{O} \%$ values for new snowfall are very similar. Thus the $5180 \%$ values for stratum 6 for all three stations are A: $-15.82 \%$, B: $-15.52 \%$ and $\mathrm{C}:-15.58 \%$ The coefficient of variation (1\%) about the mean value $(-15.64 \%$ \% is indicative of the homogeneous distribution of the new snowfalls although similar losses of meltwaters or/and evaporation losses over a short period of time at all three sites cannot be ignored completely.

As we have no density or isotope fractionation data on the original precipitation events at the time of deposition no definite conclusion on the importance of evaporation in the evolution of mesostructure can be drawn. Papineau (1983) has, however, estimated from hydrological budgets at Lake Laflamme that the maximum expected water loss due to evaporation from all forms of snow (interception and sublimation on tree canopies and snow covers on lake and ground) is low (9\%).

The profiles of sites $\mathrm{A}, \mathrm{B}$ and $\mathrm{C}$ are similar for $\mathrm{SO}_{4}^{2-}$ (Fig.2) and $\mathrm{H}^{+}$(Fig.3) while the $\mathrm{Cl}^{-}$profile of $\mathrm{A}$ and $\mathrm{B}$ is different from that of $\mathrm{C}$ (Fig.4). $\mathrm{NO}_{3}^{-}$ concentrations gave a similar pattern to $\mathrm{SO}_{4}^{2-}$ while the ionic species $\mathrm{NH}_{4}^{+}, \mathrm{K}^{+}, \mathrm{Na}^{+}, \mathrm{Ca}^{2+}$ and $\mathrm{PO}_{4}^{3-}$ gave different profiles for all three sites. The heterogeneous nature of the deposition of organic matter from the canopy has been cited as a major factor for the high degree of spatial variability of these latter species found in boreal forest snow cover (Jones and Sochanska 1985). Although large particulate organic matter such as lichen. clumps, bark, and twigs were removed at each interface between the separate strata, small amounts of debris such as needles and small particulates remained distributed throughout the snow matrix. Microbiological activity and degradation produce soluble organic compounds associated with these particular chemical species which become leached and redistributed throughout the snow cover.

Whether or not the different profiles of $\mathrm{Cl}^{-}$and $\mathrm{SO}_{4}^{2-}$ are due to the original deposition patterns in the pack, subsequent dry deposition of aerosols or of organic debris, or of different migration patterns for the ionic species down through the pack, cannot be precisely defined with the current data. $\mathrm{Cl}^{-}$is generally thought of as a conservative ion in snowpack and meltwater chemistry (Skartveit and Gjessing 1979). The calculated mean volume-weighted concentration for $\mathrm{Cl}^{-}$in profile $\mathrm{C}$ $\left(10.5 \mu \mathrm{eq} 1^{-1}\right)$ is lower than that of B $\left(15.6 \mu \mathrm{eq} 1^{-1}\right)$. In the event that horizontal homogeneous deposition of $\mathrm{Cl}$ in new snowfall and in subsequent dry deposition originally took place, the differences are significant and would suggest that $\mathrm{Cl}^{-}$has migrated down and out of the pack relatively faster at the open site $C$ than at site $B$ which has more canopy cover. On the other hand, mean volume-weighted concentration of $\mathrm{SO}_{4}^{2-}$ at the two sites are similar (B: $19.1 \mu$ eq $1^{-1}$, C: $21.2^{4} \mu$ eq $\mathrm{I}^{-1}$ ) suggesting different migration mechanisms for $\mathrm{SO}_{4}^{2-}$ and $\mathrm{Cl}^{-}$in the pack. The differences in the profiles for $\mathrm{SO}_{4}^{2-}$ in the upper strata at $\mathrm{B}$ and in those at $\mathrm{C}$ may be attributed to a relatively faster downward migration of $\mathrm{SO}_{4}^{2-}$ in the pack at site $\mathrm{C}$ due to the increased penetration of meltwaters into the pack from the topmost strata. This would also agree with the relative values of $\delta^{18} \mathrm{O} \%$ at each site. This migration pattern accounts for the different profiles of $\mathrm{H}^{+}$concentrations which are strongly correlated with $\mathrm{SO}_{4}^{2-}$ concentrations in snow strata (Table I).

Correlation coefficients between data relating the concentration of ionic species $\mathrm{Al}$ and $\mathrm{Mn}$ in the snow strata of 9 April 1983 are shown in Table I. $\mathrm{H}^{+}, \mathrm{SO}_{4}^{2-}$ and $\mathrm{NO}_{3}^{-}$concentrations are significantly correlated as are those of $\mathrm{Al}$ and $\mathrm{K}^{+}$with $\mathrm{Ca}^{2+}, \mathrm{Mg}^{2+}$ and $\mathrm{Mn}$. Factor analysis (Fig.5) shows the strong association between $\mathrm{H}^{+}$, $\mathrm{SO}_{4}^{2+}$ and $\mathrm{NO}_{3}^{-}$and the vertical factor may be regarded as representing the atmospheric contribution to the snow cover. The strong regrouping of all other chemical species

HORIZONTAL FACTOR 1 VERTICAL FACTOR 2

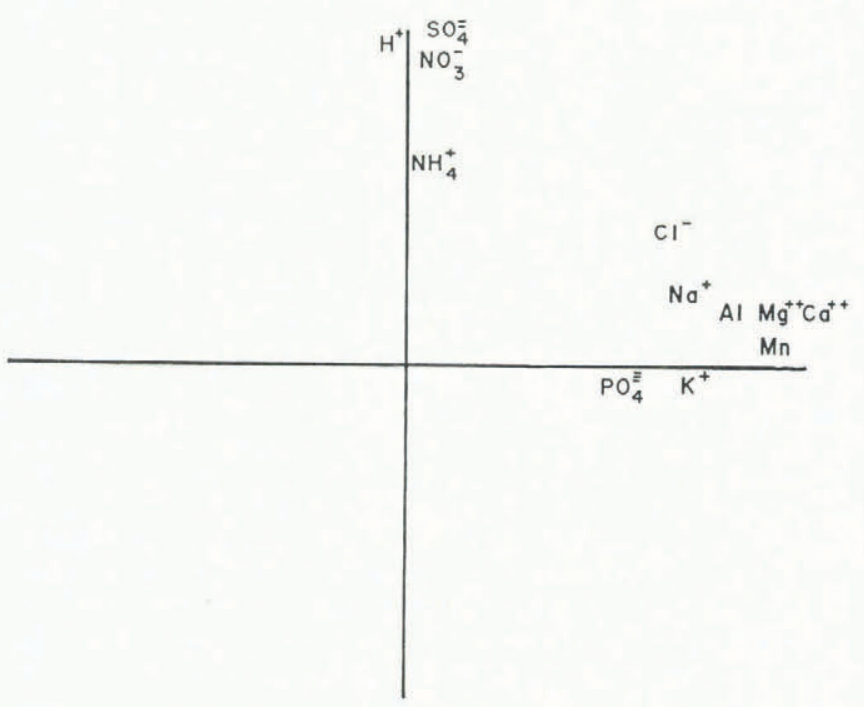

SNOWSTRATA (April 9)

Fig.5. Factor analysis for chemical species in the snow strata composing the vertical profile of the snow cover at three sampling sites, Lake Laflamme, 1983. 
TABLE I. CORRELATION COEFFICIENTS BETWEEN DATA RELATING THE CONCENTRATIONS OF CHEMICAL SPECIES IN THE SNOW STRATA COMPOSING THE VERTICAL PROFILE OF THE SNOW COVER AT THREE SAMPLING SITES, LAKE LAFLAMME, 1983

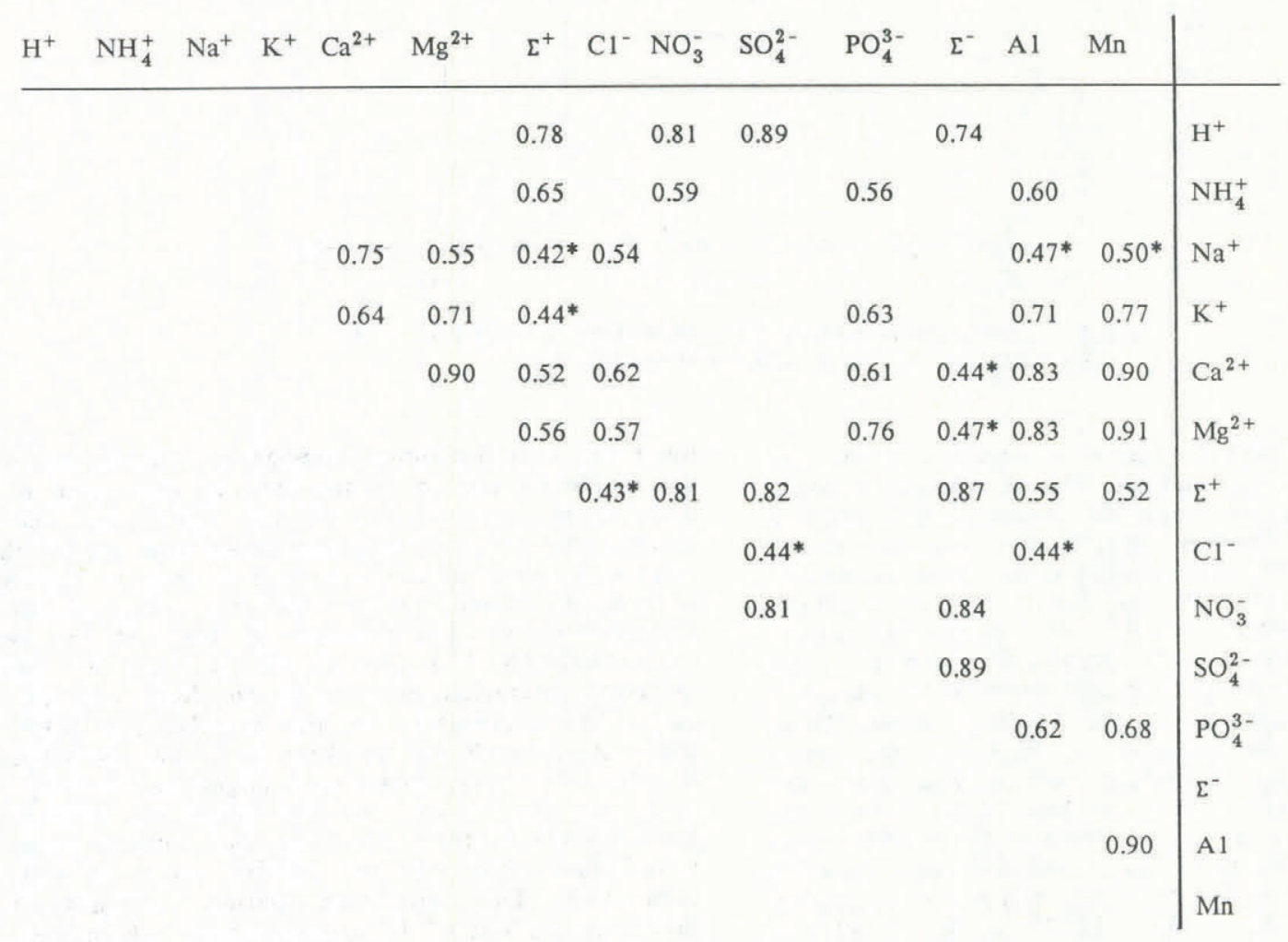

$\mathrm{n}=32 \mathrm{~m} \quad \mathrm{P} \leqslant 0.001, \mathrm{P} \leqslant 0.01^{*}$

along the extremity of the horizontal factor can be interpreted as representing the relatively high levels of materials that originate in local transport by atmospheric turbulence and local deposition of organic debris from the forest canopy. The correlation coefficients $(r=0.89)$ of data relating $\mathrm{H}^{+}$and $\mathrm{SO}_{4}^{2-}$ are comparable to those found in incident precipitation. No such correlation was found in snow cores taken on seven separate sampling occasions (on 15,21, 22, 24 and 29 March and 7 and 8 April 1983) during the stable period from the start of the study to the onset of the first recorded melts (Table II). In addition, factor analysis showed that the tight regrouping of $\mathrm{H}^{+}, \mathrm{NO}_{3}^{-}$and $\mathrm{SO}_{4}^{2-}$ observed in the case of data analysis for the strata at A, B and C was considerably weakened in similar analysis on data from snow cores. Although the number of sampling dates may not have been sufficient to establish correlations between the concentrations of the atmospheric pollutants in the snow cover as the pack was built up by successive snowfalls, both the sampling technique and the experimental procedure during analysis may have contributed to destroy the strong correlations between $\mathrm{H}^{+}$and $\mathrm{SO}_{4}^{2-}$ that may have existed in the snow matrix at the time of sampling. The snow cores contain a higher concentration of organic debris; leaching experiments on the various types of debris found on the snow cover by distilled water showed that varying amounts of ionic species $\left(\mathrm{K}^{+}, \mathrm{NO}_{3}^{-}, \mathrm{SO}_{4}^{2-}\right)$ were dissolved out of the particulate matter. During chemical analysis the snow has to be melted, and macroand micro-particulates are exposed to the leaching action of the medium. The experimental treatment of the snow-core samples from boreal forest sites can thus influence the final concentrations of certain ions in the snow as it is melted. The results of the analysis cannot therefore be used to draw definite conclusions on the chemical dynamics existing in the snowpack at the time of sampling. Data from snow strata will give more precise information on the in-pack changes associated with the different ionic species originally present in the snowfall. Snow-core samples may be, however, representative of potential total ionic loadings and chemical dynamics during periods when free water is circulating in the pack. At these times, leaching processes by free water in situ would be very similar to those occurring in meltwater produced during the procedures used on snow samples in the laboratory.

\section{Snow strata: chemical evolution}

Stratum 5 in the snow profiles at sites A, B and C represented two snowfalls on 22 and 27 March 1983, separated by a cold period $\left(\right.$ mean $=-14^{\circ} \mathrm{C}$ ). Figure 6

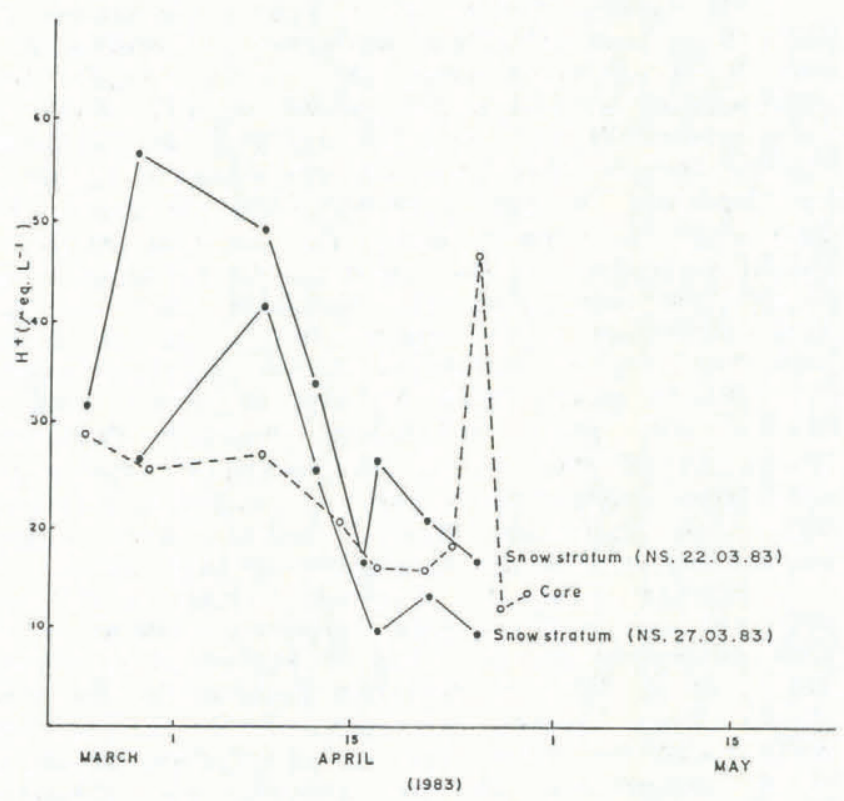

Fig.6. Evolution of $\mathrm{H}^{+}$concentrations in new snowfall (NS) and the resulting strata in the snow-cover mesostructure, Lake Laflamme, 1983. 
TABLE II. CORRELATION COEFFICIENTS BETWEEN DATA RELATING THE CONCENTRATIONS OF CHEMICAL SPECIES IN SNOW CORES TAKEN AT BASE-LINE STATIONS OF THE SNOW COVER AT LAKE LAFLAMME, 1983

\begin{tabular}{|c|c|c|c|c|c|c|c|c|c|c|c|c|c|c|}
\hline $\mathrm{H}^{+}$ & $\mathrm{NH}_{4}^{+}$ & $\mathrm{Na}^{+}$ & $\mathrm{K}^{+}$ & $\mathrm{Ca}^{2+}$ & $\mathrm{Mg}^{2+}$ & $\Sigma^{+}$ & $\mathrm{Cl}^{-}$ & $\mathrm{NO}_{3}^{-}$ & $\mathrm{SO}_{4}^{2-}$ & $\mathrm{PO}_{4}^{3-}$ & $\Sigma^{-}$ & A 1 & $\mathrm{Mn}$ & \\
\hline & & & & & & 0.66 & & & & & & & & $\mathrm{H}^{+}$ \\
\hline & & $0.36^{*}$ & & & & & & & & & & & & $\mathrm{NH}_{4}^{+}$ \\
\hline & & & & 0.37 & $0.30^{*}$ & $0.37^{*}$ & 0.50 & & $0.36^{*}$ & & $0.35^{*}$ & & & $\mathrm{Na}^{+}$ \\
\hline & & & & 0.81 & 0.87 & 0.76 & & & & & & & 0.88 & $\mathrm{~K}^{+}$ \\
\hline & & & & & 0.93 & 0.73 & & & $0.35^{*}$ & & & & 0.83 & $\mathrm{Ca}^{2+}$ \\
\hline & & & & & & 0.77 & & & $0.33^{*}$ & & & & 0.88 & $\mathrm{Mg}^{2+}$ \\
\hline & & & & & & & & & & & & & 0.67 & $\Sigma^{+}$ \\
\hline & & & & & & & & & 0.47 & 0.43 & 0.68 & & & $\mathrm{Cl}^{-}$ \\
\hline & & & & & & & & & & & 0.57 & & & $\mathrm{NO}_{3}^{-}$ \\
\hline & & & & & & & & & & 0.41 & 0.71 & & & $\mathrm{SO}_{4}^{2-}$ \\
\hline & & & & & & & & & & & 0.74 & & & $\mathrm{PO}_{4}^{3-}$ \\
\hline & & & & & & & & & & & & & & $\Sigma^{-}$ \\
\hline & & & & & & & & & & & & & & Al \\
\hline$=$ & $59, P$ & $\leqslant 0.001$ & $P$ & $\leqslant 0.01^{*}$ & & & & & & & & & & $\mathrm{Mn}$ \\
\hline
\end{tabular}

reproduces the evolution of $\mathrm{H}^{+}$concentrations in the upper and lower regions of the same stratum 5 which was sampled at a base-line station $(30 \mathrm{~m}$ from site 4$)$ from the time of the deposition of each snowfall until the disappearance of the stratum during rainfall on 25 April 1983. The layers of snow due to each individual snowfall had become indistinguishable from one another by 8 April; their locations were pinpointed from previous holes remaining after side-coring. The decline in acidity, which commenced on 8 April, was due to meltwater movement down to the lower layers of the pack. The rise of acidity of the new snowfall from 22 to 28 March 1983 is, however, significant; it does suggest that deposition of acidic pollutants on the pack during this period had occurred. We have, unfortunately, very little complementary data which we could use to distinguish between dry deposition and any other phenomena such as biological activity. Conductivity values for the snow stratum rose little during this period (10 to $\left.11.2 \mu \mathrm{S} \mathrm{cm}^{-1}\right)$ but $\mathrm{NH}_{4}^{+}$concentrations dropped significantly (15.61 to $3.94 \mu \mathrm{eq} \mathrm{l}^{-1}$ ). If any chemical or biological activity in snowpacks during certain periods does remove $\mathrm{NH}_{4}^{+}$ (Ramadori and others 1984), the net effect would be to increase $\mathrm{H}^{+}$ionic loadings in the pack.

\section{Meltwater: movement and chemical composition}

The data from $8^{18} \mathrm{O} \%$ a and the composition of ionic species in the snow profile is indicative that small amounts of meltwater move in a uniform manner down through the snow mesostructure. When free water started circulating through the pack in large quantities during rain episodes and high melt rates, it was obvious, from the visual observation of the faces of the snowpits and from the volumes and $\mathrm{pH}$ values of meltwater samples collected by the small lysimeters (Fig.7), that both the flow and the acidity of the discharge varied appreciably within the snowpack structure. The pathway of meltwater and/or rain through the snowpack is dependent on the mesostructural characteristics such as ice lenses, stratified snow layers of differing density, drip zones of conifers and organic debris. These factors combine to produce both vertical and horizontal pipeflow patterns which were exposed by selected snow-pit excavations as the melt season progressed. Vertical pipeflow was prevalent under the drip zones of conifers while horizontal pipeflow patterns were found to be particularly orientated by the snow-ice lens interfaces. The fact that these pipeflow patterns also changed with time leads to a very complex hydrological system which is far removed from the idealized flow
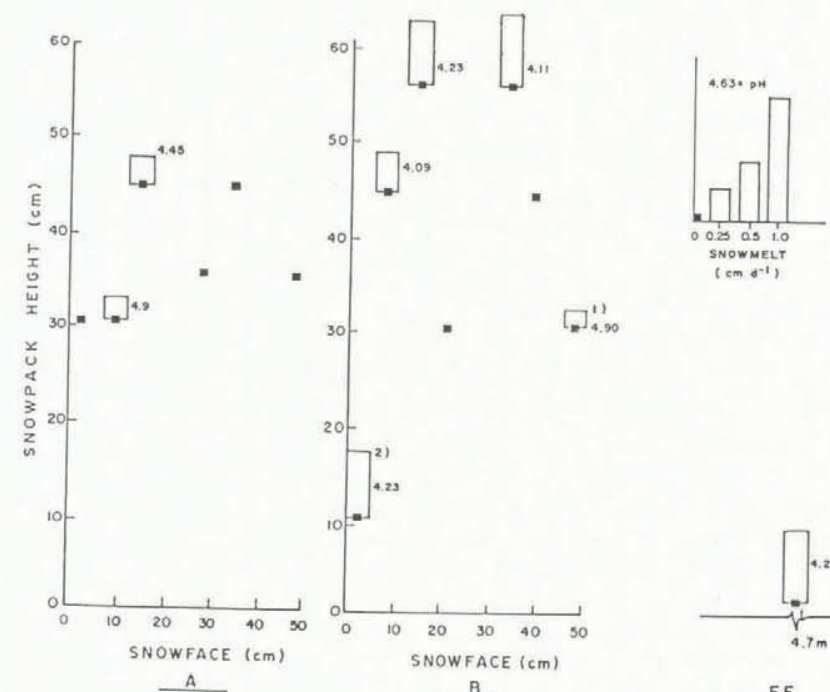

Fig.7. Meltwater flow rates $\left(\mathrm{cm} \mathrm{d}^{-1}\right)$ and $\mathrm{pH}$ values for small lysimeters on 25 April 1983 inserted at different levels in the vertical profile of the snow cover at two sites (A, B) at Lake Laflamme, 1983. EF represents the flow and $\mathrm{pH}$ values for a large lysimeter $\left(19.8 \mathrm{~m}^{2}\right)$ at the same time. 1 and 2 are lysimeter 1 and 2 respectively (see Fig. 8). 


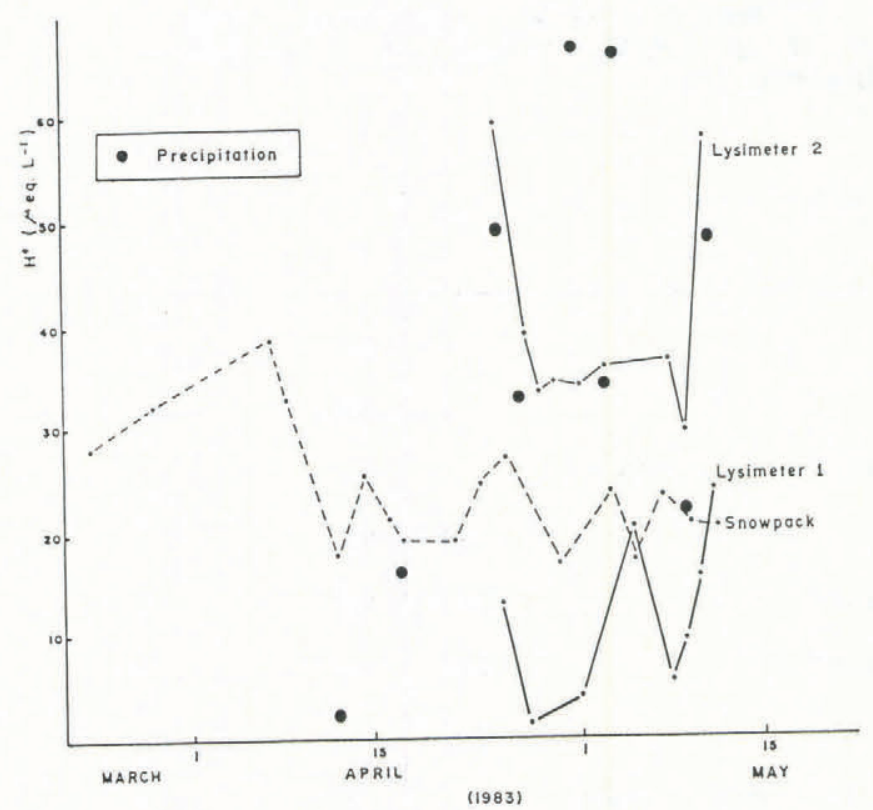

Fig.8. $\mathrm{H}^{+}$concentrations in the snow cover, precipitation and meltwaters collected by two small lysimeters $(0.1$ $\mathrm{m}^{2}$ ) placed at different levels in the snowpack at site B, Lake Laflamme, spring 1983.

conditions which are found in some snowpacks (Colbeck 1972, Jordan 1983). When the residence time of incident precipitation of high acidity in the snow structure is short, leading to vertical pipeflow, little dilution of the descending free water can take place and the acidity levels $\left(\mathrm{H}^{+}\right)$of the discharged meltwaters will remain high. On the other hand, horizontal pipeflow with a relatively long residence time will tend to have reduced concentrations of $\mathrm{H}^{+}$due to cationic leaching and ion exchange capacity of organic matter. Figure 8 reproduces $\mathrm{H}^{+}$concentrations of meltwaters from two of the small lysimeters at site $B$ during the main melt period (25 April to 11 May 1983). Meltwater from lysimeter 2 showed high concentrations of $\mathrm{H}^{+}$which in many cases were similar to the precipitation falling on the pack (20 to $\left.80 \mu \mathrm{eq} 1^{-1}\right)$. In contrast, meltwater samples collected by lysimeter 1 showed appreciable reduction in $\mathrm{H}^{+}$ concentration ( 2 to $\left.25 \mu \mathrm{eq} \mathrm{l}^{-1}\right)$. Concentrations of sulphate in the two lysimeters were similar and the low $\mathrm{H}^{+}$ concentrations in lysimeter 1 were attributed to removal of $\mathrm{H}^{+}$by organic matter associated with the high $\mathrm{K}^{+}$ concentrations $\left(\left[\mathrm{K}^{+}\right]=16 \mu \mathrm{eq} 1^{-1}\right.$, maximum range 7.2 to $30.4 \mu \mathrm{eq} \mathrm{1^{-1 }}$ ) found in the meltwaters of lysimeter 1 . These particular meltwaters originated from the pipeflow of a channel which was observed to contain large amounts of organic debris. Although the extent to which the small lysimeters influenced pipeflow conditions during diurnal freeze and melt cycles by allowing air intrusion into the pack was not determined, the results of the experiment did show that the flux of ionic loading (meq $\mathrm{m}^{-2} \mathrm{~d}^{-1}$ ) of the snow cover as calculated from the lysimeters varied considerably between sites $A$ and $B$ and from one lysimeter to another. These observations can account for the increased chemical heterogeneity of snow cover calculated from data obtained from snow cores sampled during rain episodes. During these periods, the heterogeneous nature of the pipeflow patterns will cause the chemical composition in the pack to change both rapidly and in a non-uniform manner as the free water circulates through the snow cover. This would also account for the observation that the coefficients of variation of all chemical species in the snow pack increased significantly around the mean values during rain events (Jones and others 1984).

\section{CONCLUSION}

The physical and chemical characteristics of successive snowfalls in a boreal forest site constitutes a relatively uniform mesostructure which is affected little by wind redistribution. Small movements of water in the pack before the continual meltwater discharge in spring redistribute chemical species deeper into the pack but this may be compensated by additional deposition processes. Chemical and physical characteristics of the mesostructure break down rapidly but not uniformly over the snowfield during rapid free water movement through pipeflow channels. Organic litter deposition is a prominent feature of snow mesostructure in boreal forest sites. The influence of this debris on the chemical quality of snow during the experimental preparation of snow samples leads to the conclusion that data obtained from carefully sampled snow strata will give more precise information on the nature of chemical dynamics of atmospheric pollutants resident in snowpacks at boreal forest sites than analogous data from snow-core studies.

\section{REFERENCES}

Adams W P, Glew J R, Outerbridge V C, Strickland N A 1982 Evolution of snowcover at Pasture and Bush sites, and illustration of techniques. Monograph (Ontario Association for Geographical and Environmental Education) 33(1): 6-11

Colbeck S C 1972 A theory of water percolation in snow. Journal of Glaciology 11(63): 369-385

Herrmann A, Lehrer M, Stichler W 1981 Isotope input into runoff systems from melting snow covers. Nordic Hydrology 12(4-5): 309-318

Jeffries D S, Snyder W R 1981 Variations in the chemical composition of the snowpack and associated meltwaters in central Ontario. Proceedings of the Eastern Snow Conference, 38 th annual meeting: 11-22

Jones H G, Sochanska W 1985 The chemical characteristics of snow cover in a northern boreal forest during the spring run-off period. Annals of Glaciology 7: 167-174

Jones H G, Sochanska W, Bougie R, Charette J Y 1984 Développement d'une méthodologie d'étude sur les facteurs contrôlant la qualité des eaux de fonte et des eaux de ruissellement printanier au lac Laflamme, Québec. Sainte-Foy, Québec, Environnement Canada. Direction Générale des Eaux Intérieures (INRS-Eau, Rapport Scientifique 165)

Jordan P 1983 Meltwater movement in a deep snowpack. 1. Field observations. Water Resources Research 19(4): 971-978

Langham E J 1974 The occurrence and movement of liquid water in the snowpack. In Santeford H S, Smith J L (eds) Advanced concepts and techniques in the study of snow and ice resources; an interdisciplinary symposium ... Monterey, California. December 2-6, 1973. Washington, DC, National Academy of Sciences: 67-75

McKay G A, Gray D M 1981 The distribution of snowcover. In Gray D M, Male D H (eds) Handbook of snow; principles, processes, management and use. Toronto etc, Pergamon Press: 153-190

Papineau M 1983 Le bassin du lac Laflamme: caractérisation physico-chimique du lac et établissement du bilan ionique en relation avec le transport à grande distance des polluants atmosphériques. Sainte-Foy, Québec, Environnement Canada. Direction Générale des Eaux Intérieures (Rapport Interne)

Ramadori R, Rozzi A, Tandoi V 1984 An automated system for monitoring the kinetics of biological oxidation of ammonia. Water Research 14: 1555-1557

Skartveit A, Gjessing Y T 1979 Chemical budgets and chemical quality of snow and runoff during spring sn乞wmelt. Nordic Hydrology 10(2-3): 141-154 